\title{
IMPLEMENTASI KEBIJAKAN PENANGGULANGAN BENCANA DAERAH DI KOTA SUKABUMI
}

\author{
Nabila Rahma Silmi ${ }^{1}$, Tuah Nur ${ }^{2}$, Dian Purwanti ${ }^{3}$ \\ Universitas Muhammadiyah Sukabumi ${ }^{1,2,3}$ \\ nabilarahmas97@gmail.com ${ }^{1}$
}

\begin{abstract}
ABSTRAK
Tujuan dalam penelitian ini adalah untuk mengetahui implementasi kebijakan penanggulangan bencana daerah di Kota Sukabumi dan untuk mengetahui faktor penghambat dan faktor pendukung dari keberhasilan implementasi kebijakan penanggulangan bencana daerah. Metode penelitian ini menggunakan metode deskriptif analisis dengan pendekatan kualitatif. Hasil penelitian menunjukkan bahwa implementasi kebijakan penanggulangan bencana daerah belum optimal. Simpulannya dilihat dari kegiatan sosialisasi masih kurang dan merata, sumber daya manusia dan sarana prasarana masih belum ada penambahan. Faktor penghambatnya adalah dari segi kelembagaan, disiplin aparatur, anggaran, sumber daya, fasilitas dan lingkungan yang kurang kondusif. Faktor pendukungnya adalah adanya regulasi atau peraturan tentang penanggulangan bencana. untuk komunikasi yang di lakukan BPBD Kota Sukabumi dalam melalukan kegiatan sosialisasi atau pelatihan mengenai penanggulangan bencana kepada masyarakat masih kurang dan belum merata.
\end{abstract}

Kata Kunci: Implementasi, Kebijakan, Penanggulangan Bencana.

\section{ABSTRACT}

The purpose of this research is to find out the implementation of regional disaster management policies in Sukabumi City and to find out the inhibiting and supporting factors of the successful implementation of regional disaster management policies. This research method uses descriptive analysis method with a qualitative approach. The results showed that the implementation of regional disaster management policies was not optimal. The conclusion is that the socialization activities are still lacking and equitable, human resources and infrastructure have not been added yet. The inhibiting factors are in terms of institutional, apparatus discipline, budget, resources, facilities and environment that are less conducive. Supporting factors are the existence of regulations or regulations on disaster management. for communication carried out by $B P B D$ Sukabumi City in carrying out socialization activities or training on disaster management to the public is still lacking and uneven.

Keywords: Implementation, Policy, Disaster Management.

\section{PENDAHULUAN}

Pusat Vulkanologi dan Mitigasi Bencana Geologi (PVMBG) merilis data terbaru peringatan dini pergerakan tanah per-Desember 2018. Dari data tersebut, tercatat enam Kecamatan di Kota Sukabumi masuk kategori rawan bencana pergerakan tanah 
yaitu Kecamatan Cibeureum, Cikole, Citamiang, Warudoyong, Lembursitu dan Gunungpuyuh. Tiga kecamatan, yakni Kecamatan Cibeureum, Warudoyong dan Gunungpuyuh masuk kategori potensi bencana banjir bandang. Bencana tanah longsor dan banjir di Kota Sukabumi terus meluas, titik bencana yang sebelumnya hanya terjadi di dua titik berbeda, kini bertambah menjadi empat titik yang berada di areal merah potensi bencana. Kesiapsiagaan dalam menghadapi bencana alam merupakan hal yang sangat penting dan harus menjadi suatu kebutuhan bagi kehidupan masyarakat, terutama yang bertempat tinggal di daerah rawan bencana, penanggulangan bencana alam tidak bisa dilakukan dengan cara mendadak atau insidentil, tetapi harus dengan terencana dengan manajemen yang baik, jauh hari sebelum bencana terjadi melalui sebuah proses yang disebut manajemen bencana. Penyelenggaraan penanggulangan bencana adalah suatu upaya yang meliputi penetapan kebijakan pembangunan yang beresiko timbulnya bencana, kegiatan pencegahan bencana, tanggap darurat bencana dan rehabilitasi.

Penanggulangan bencana menjadi tanggungjawab bersama, sebagaimana yang dijelaskan dalam Peraturan Daerah Kota Sukabumi Nomor 7 Tahun 2017 tentang Penyelenggaraan Penanggulangan Bencana, baik pemerintah, swasta maupun seluruh eleman lapisan masyarakat ikut bertanggungjawab dalam penanggulangan bencana untuk keselamatan diri, keluarga serta lingkungan tempat hidupnya. Pemerintah Kota Sukabumi menjadi penanggungjawab dalam pencegahan, penanggulangan bencana, kesiapsiagaan dan peringatan dini terjadinya bencana dalam penyelenggaraan penanggulangan bencana di wilayah Kota Sukabumi. Dalam Undang-Undang Nomor 24 tahun 2007 menyebutkan bahwa setiap daerah harus melakukan persiapan sebelum, sesaat dan sesudah tragedi. Hal-hal terpenting yang perlu diperhatikan oleh masyarakat terlebih dahulu adalah pemetaan bangunan, pemetaan lapisan tanah, pemberdayaan manusia dan penelitian lebih lanjut.

Berdasarkan hasil penelitian Setyowati (2018) permasalahan komunikasi muncul ketika tidak adanya kesepakatan antara pengambil kebijakan, pelaksana kebijakan dan penerima kebijakan, akan tetapi hal ini telah diselesaikan dengan proses komunikasi secara kultular. Faktor penghambat kebijakan penanggulangan bencana daerah di BPBD Kabupaten Sukabumi adalah luasnya wilayah Kabupaten Sukabumi dan faktor kesadaran masyarakat yang masih rendah. Sedangkan faktor pendukungnya adalah adanya dukungan dari organisasi kemasyarakatan kebencanaan, instansi terkait saling mendukung dan memfasilitasi, Perbup tentang tata naskah dinas resmi dilaksanakan dan ditaati setiap instansi.

Berdasarkan hasil observasi awal peneliti mengenai Impelementasi Kebijakan Penanggulangan Bencana Daerah, masyarakat Kota Sukabumi ditemukan fenomena masalah sebagai berikut: 1) komunikasi yang dilakukan mengenai mitigasi bencana ini masih kurang, contoh masih kurangnya kesadaran dan kerjasama di lingkungan SKPD dan masyarakat tentang mitigasi bencana yang bisa dilihat dari sosialisasi yang belum optimal serta kurangnya kesadaran pentingnya menjaga keseimbangan lingkungan di lingkungan masyarakat agar tidak mengakibatkan terjadinya bencana alam, 2) sumber daya yang ada di Badan Penanggulangan Bencana Daerah Kota Sukabumi masih 
kurang, ini bisa dilihat dari; a) jumlah sumber daya manusia yang ada di BPBD Kota Sukabumi adalah 53 orang, sedangkan menurut Kepala BPBD kota Sukabumi idealnya jumlah tenaga kerja yang harus ada adalah 73 orang, b) sarana dan prasarana yang dimiliki oleh BPBD Kota Sukabumi pun secara keseluruhan dapat dikatakan masih kurang. Contoh belum adanya alat berat beko kecil, loder kecil dan lain-lain. Tujuan penelitian ini adalah ntuk mengetahui bagaimana implementasi kebijakan tentang penanggulangan bencana daerah dan untuk mengetahui faktor penghambat dan faktor pendukung dari keberhasilan implementasi kebijakan tentang penanggulangan bencana daerah.

\section{METODE PENELITIAN}

Penelitian ini menggunakan pendekatan kualitatif, yang pada dasarnya penelitian kualitatif dilaksanakan dalam keadaan yang alamiah (natural setting) dan data yang dikumpulkan umumnya bersifat kualitatif. Pada penelitian ini yang menjadi indikator penelitian adalah implementasi kebijakan publik di Badan Penanggungan Bencana Daerah (BPBD) Kota Sukabumi. Teknik penentuan informan yang digunakan dalam penelitian ini menggunakan nonprobability sampling dengan metode snawball sampling, yaitu teknik pengambilan sampel sumber data yang awalnya jumlahnya sedikit, lama-lama menjadi besar seiring berjalannya penelitian serta perlunya pendalaman informasi yang diperlukan dalam melengkapi data yang diperlukan. Untuk menentukan informan mengenai implementasi penanggulangan bencana daerah di kota sukabumi memerlukan informan yang mempunyai pemahaman yang berkaitan dengan masalah penelitian guna memperoleh data dan informasi yang lebih akurat.

\section{HASIL PENELITIAN}

\section{Komunikasi}

Komunikasi merupakan hal terpenting dan sangat menentukan keberhasilan pencapaian tujuan dari implementasi kebijakan publik. implementasi yang efektif terjadi apabila para pembuat keputusan sudah mengetahui apa yang akan mereka kerjakan. Kebijakan yang dikomunikasikan harus tepat, akurat dan konsisten. Komunikasi atau pentransmisian informasi diperlukan agar para pembuat keputusan dan para implementator akan semakin konsisten dalam melaksanakan setiap kebijakan yang akan di terapkan dalam masyarakat. Untuk melihat bagaimana komunikasi para pelaksana kebijakan penanggulangan bencana di Kota Sukabumi, maka peneliti mencoba mencari tahu kepada beberapa informan yang terlibat dalam penelitian ini. Pertanyaan yang peneliti ajukan kepada informan 1 adalah, bagaimana komunikasi yang di lakukan BPBD Kota Sukabumi kepada masyarakat dan pihak-pihak terkait dalam penanggulangan bencana di Kota Sukabumi? Jawaban dari informan 1 adalah :

Komunikasi yang dilakukan di kita sifatnya koordinasi, terutama dengan Satuan Kerja Perangkat Daerah (SKPD) lain yang memang ada kaitannya dengan penanggulangan bencana seperti Dinas Sosial, Dinas Kesehatan, Dinas PUPR dan lain-lain. Selain itu kita juga melakukan koordinasi dengan 
beberapa organisasi yang khusus menyangkut tentang kebencanaan, contohnya organisasi PMI, Gorila (Gunung, rimba dan laut) dan relawan-relawan. Komunikasi yang dilakukan memang belum optimal, pada pra bencana sosialisasi yang dilakukan hanya 3-4 kali dalam setahun. Selain itu, pada saat dan pasca bencana juga komunikasinya masih kurang. Artinya disini contohnya ketika bencana tanah longsor, banjir atau gempa yang dapat menimbulkan kerusakan infrastruktur sehingga harus di perbaiki atau pembangunan fisik, itu kan di luar ranah kita artinya dilakukan oleh Dinas lain, kita hanya dalam kebencanaan nya saja. Dinas lain pun bukannya tidak memperbaiki, namun karena keterbatasan anggaran sehingga memperlambat perbaikan. Banyak orang mengatakan bahwa koordinasi ini mudah diucapkan namun sulit untuk dilakukan. (Wawancara 18 Januari 2019)

Dari pernyataan semua informan diatas mengenai komunikasi yang dilakukan dalam kebijakan penanggulangan bencana di Kota Sukabumi dapat diinterpretasikan bahwa, komunikasi yang dilakukan secara koordinasi dengan Satuan Kerja Perangkat Daerah (SKPD) maupun lintas sektoral sudah terjalin- cukup baik dengan melakukan rapat koordinasi pada saat terjadi bencana maupun tidak terjadi bencana. Namun untuk komunikasi dalam mensosialisasikan kebijakan mengenai penyelenggaraan penanggulangan bencana di Kota Sukabumi belum maksimal dan belum merata. Sehingga masih ditemukan kurangnya kesadaran masyarakat dalam menjaga lingkungan sekitar dengan masih membuang sampah ke aliran-aliran sungai yang akan mengakibatkan banjir apabila hujan deras.

\section{Sumber Daya}

Sumber daya yaitu menunjuk setiap kebijakan yang harus didukung oleh sumber daya yang memadai. Dalam mengimplementasikan suatu program kebijakan perlu didukung dengan sumber-sumber yang memadai, baik itu sumber daya manusia, sumber daya alam, sumber financial, maupun fasilitas atau sarana dan prasarana nya. Sumber daya manusia adalah kecukupan baik kualitas maupun kuantitas implementator yang dapat melingkupi seluruh kelompok sasaran. Sedangkan sumber daya alam adalah segala sesuatu yang berasal dari alam yang dapat dimanfaatkan untuk kebutuhan hidup manusia. Dan sumber daya financial disini adalah jumlah anggaran yang dikeluarkan pemerintah dalam mengimplementasikan kebijakan tersebut. Sarana dan prasarana juga merupakan faktor pendukung keberhasilan dari sebuah program atau kebijakan. Jadi sumber daya manusia, sumber daya alam, sumber daya financial dan sarana prasarana semuanya saling berhubungan dan berkaitan satu sama lain. Tanpa ada dukungan- yang memadai dari sumber daya tersebut maka suatu program atau kebijakan itu tidak akan berjalan dengan efektif dalam mencapai tujuan dan sasarannya.

Maka dari itu peneliti ingin mengetahui bagaimana sumber daya yang ada

dalam kebijakan penanggulangan bencana di Kota Sukabumi dalam mengimplementasikan kebijakan tersebut dengan memberikan pertanyaan berikut :bagaimana sumber daya yang ada dalam pelaksanaan kebijakan penanggulangan 
bencana di Kota Sukabumi?. Lalu informan 1 memberikan jawaban atas pertanyaan peneliti dengan jawaban berikut :

Untuk sumber daya manusia yang ada di BPBD ini berjulmah 53 orang yang masuk ke dalam struktur organisasi BPBD, yang terdiri dari 29 PNS, 22 THL, 2 TKS di tambah relawan yang aktif sekitar 15 orang. Cukup atau tidaknya tergantung aturan yang telah di tentukan, jika melihat analisa beban kerja itu memang kurang. Contohnya di pemadam kebakaran disini terdapat 6 unit kendaraan pemadam kebakaran yang masing-masing kendaraan terdapat 5 personil, sedangkan seharusnya berjumlah 7 personil setiap kendaraan itu. Selain itu staf juga masih kurang, jadi jika di totalkan membutuhkan kurang lebih 20 orang untuk penambahannya. Sedangkan untuk anggaran kita cukup tidak cukup ya, artinya kita sudah melakukan kegiatan sesuai dengan anggaran yang sudah ditentukan meskipun kegiatan nya mungkin belum maksimal. Untuk jumlah anggaran di kita pertahun kurang lebih $2 \mathrm{M}$. Dan untuk sarana prasarana yang ada di kita ini memang masih ada peralatan yang kurang yang belum kita miliki misalnya doser, beko kecil, alat tradisional seperti cangkul dan komputer." (Wawancara 11 Juli 2019)

Dari hasil wawancara dengan para informan, peneliti menginterpretasikan bahwa sumber daya yang ada di BPBD Kota Sukabumi masih kurang. Ini bisa dilihat dari jumlah staff yang ada dalam pelaksanaan kebijakan penanggulangan bencana tersebut masih kurang, sehingga perlu penambahan pegawai secara kuantitas dan kualitas. Karena penambahan jumlah staf saja tidak mencukupi, tetapi diperlukan pula kecukupan staf dengan keahlian serta kemampuan yang diperlukan dalam melaksanakan tugasnya. Keseimbangan antara beban kerja dengan jumlah personel akan membuat implementasi akan berjalan lebih efektif. Selain itu, dilihat dari fasilitas atau sarana dan prasarana yang ada di BPBD Kota Sukabumi masih kurang memadai dan belum ada peningkatan.

\section{Disposisi}

Kecenderungan perilaku atau karakteristik dari pelaksana kebijakan berperan penting untuk mewujudkan implementasi kebijakan yang sesuai dengan tujuan atau sasaran. Karakter penting yang harus dimiliki oleh pelaksana kebijakan misalnya kejujuran dan komitmen yang tinggi. Kejujuran mengarahkan implementator untuk tetap berada dalam program yang telah di tentukan, sedangkan komitmen yang- tinggi dari pelaksana kebijakan akan membuat mereka selalu antusias dalam melaksanakan tugas, wewenang, fungsi dan tanggungjawab sesuai dengan peraturan yang telah ditetapkan. Sikap dari pelaksana kebijakan akan sangat berpengaruh dalam proses implementasi kebijakan penanggulangan bencana ini. Apabila implementator memiliki sikap yang baik maka dia akan menjalankan kebijakan dengan baik pula seperti apayang di inginkan oleh pembuat kebijakan. Dan sebaliknya apabila sikapnya tidak mendukung maka implementasi kebijakan tersebut tidak akan terlaksana dengan baik. Maka dari itu peneliti ingin mengetahui bagaimana disposisi implementator dalam kebijakan penanggulangan bencana di Kota Sukabumi dengan memberikan pertanyaan 
kepada informan 1 berikut ini :bagaimana disposisi yang dilakukan dalam kebijakan penanggulangan bencana di Kota Sukabumi?. Lalu informan 1 memberikan tanggapan atas pertanyaan peneliti dengan jawaban berikut :

Sikap atau tugas kita lakukan sesuai dengan SOP yang kita miliki, jika terjadi bencana apa yang harus kita lakukan masing-masing harus sudah bisa memahami apa yang harus dilakukan mulai dari Kepala, Sekretaris, Kepala Seksi dan staff. Artinya siapa dan berbuat apanya sudah jelas sesuai dengan SOP. Pertanggungjawaban dan komitmen di kita memang sesuai dengan apa yang kita buat dalam perjanjian kinerja.(Wawancara 11 Juli 2019)

Dari hasil wawancara tersebut dapat disimpulkan bahwa disposisi yang dimana dalam penelitian ini adalah sikap dari pelaksana kebijakan sudah berjalan cukup baik sesuai dengan tugas dan wewenangnya masing-masing, sehingga para pelaksana sudah bertanggungjawab dan berkomitmen dalam melaksanakan tugasnya. Tanggungjawab atas tugas pun sudah baik, para pelaksana sudah melaksanakan tugas dan wewenangnya sesuai dengan peraturan dan komando yang telah ditentukan. Apablia implementator memiliki disposisi yang baik, maka dia dapat melaksanakan kebijakan dengan baik pula seperti apa yang diinginkan oleh pembuat kebijakan, sehingga proses implementasi kebijakan menjadi efektif. Menurut Edward III mengayatakan bahwa karakter yang penting dimiliki oleh implementator adalah kejujuran, komitmen dan demokratis. Implementator yang memiliki komitmen yang tinggi dan jujur akan senantiasa bertahan diantara hambatan yang ditemui dalam program atau kebijakan.

\section{Struktur Birokrasi}

Struktur birokrasi memiliki pengaruh yang signifikan terhadap implementasi kebijakan. Aspek struktur organisasi ini melingkupi dua hal yaitu mekanisme dan struktur birokrasi itu sendiri. Yang pertama adalah mekanisme, dalam implementasi kebijakan biasanya sudah di buat Standart Operation Procedure (SOP). SOP ini menjadi pedoman bagi setiap implementator dalam bertindak agar dalam pelaksanaan kebijakan tidak menyimpang dari tujuan dan sasaran kebijakan tersebut. Yang kedua adalah struktur birokrasi, apabila struktur birokrasi terlalu panjang dan terfragmentasi akan cenderung melemahkan pengawasan dan menyebabkan prosedur birokrasi yang rumit dan kompleks, yang selanjutnya akan menyebabkan aktivitas organisasi menjadi tidak fleksibel.

Dalam implementasi kebijakan ada satu hal yang penting di tambahkan yaitu diskresi atau ruang gerak bagi individu pelaksana kebijakan, tidak mengatur atau mengatur berbeda dengan kondisi di lapangan. Diskresi adalah kehormatan fungsional para pelaksana implementasi kebijakan. Karena kebijakan pada tingkat tertentu selalu diperlukan penyesuaian dengan implementasi. Maka dari itu peneliti ingin mengetahui bagaimana struktur birokrasi dalam kebijakan penanggulangan bencana di Kota Sukabumi dengan memberikan pertanyaan kepada informan 1 dan informan lainnya yaitu, bagaimana pengaturan struktur birokrasi yang dilakukan dalam kebijakan 
penanggulangan bencana di Kota Sukabumi?. Lalu informan menanggapi pertanyaan peneliti tersebut dengan jawaban berikut :

Kita melakukan kebijakan penanggulangan bencana ini sudah sesuai dengan SOP yang telah dibuat dari mulai saat BPBD ini berdiri yaitu pada tahun 2013, namun ada sedikit perubahan dari hasil evaluasi dari tahun ke tahun. Struktur organisasi, tugas pokok dan fungsi serta tata kerja dari pada penanggulangan bencana itu dasarnya adalah Peraturan Walikota Sukabumi Nomor 53 Tahun 2016. Yang di dalamnya ada yang di kepalai oleh Kepala Badan, satu orang Sekretaris dengan pekerjaannya di bidang perencanaan, penganggaran dan bidang umum sarana dan prasarana. Dan secara operasional di bantu oleh 4 Seksi. Yang pertama Seksi Pencegahan dan Kesiapsiagaan, Seksi Rehabilitasi dan Rekonstruksi, Seksi Kedaruratan dan Logistik dan terakhir Seksi Pemadam Kebakaran. Setiap Seksi di bantu oleh 2-3 orang dan masih kurang harusnya ada 5-6 orang per tiap Seksinya." (Wawancara 11 Juli 2019)

Dari hasil wawancara diatas peneliti menginterpretasikan bahwa salah satu dari aspek struktur yang penting dari setiap organisasi adalah adanya prosedur operasi standar/Standart Operating Procedure (SOP). SOP menjadi pedoman bagi setiap implementator dalam bertindak. Dalam mengimplementasikan kebijakan penanggulangan bencana para pelaksana kebijakan telah bekerja dan berpedoman sesuai dengan SOP yang telah dibuat. Selain itu, struktur organisasi merupakan hal yang berpengaruh terhadap implementasi kebijakan. Apabila struktur organisasi antara pegawai terkoordinasi dengan baik, maka implementasi kebiakan tersebut akan terealisasikan dengan lancar. Struktur organisasi merupakan hal utama dalam mengorganisasikan aktivitas dari sumber daya manusia yang tersedia di Badan Penanggulangan Bencana Daerah (BPBD) Kota Sukabumi agara semua pekerjaan dilaksanakan dengan baik. Menurut Edward III struktur organisasi yang terlalu panjang akan cenderung melemahkan pengawasan dan menimbulkan red-tape yaitu prosedur birokrasi yang rumit dan kompleks.

\section{PEMBAHASAN}

\section{Komunikasi}

Komunikasi kebijakan merupakan proses penyampaian informasi dari pembuat kebijakan kepada pelaksana kebijakan, begitupun dari pelaksana kebijakan kepada pengguna atau sasaran dari kebijakan tersebut. Sehingga salah satu cara agar kebijakan itu terkomunikasikan dengan baik, maka harus dilakukan sosialiasi tentang program dan isi dari kebijakan penanggulangan bencana tersebut kepada masyarakat secara continue dan menyeluruh. Karena untuk mengimplementasikan kebijakan tersebut komunikasi antar sesame implementator kebijakan dan sasaran kebijakan sangat penting agar implementasi dapat berjalan dengan baik dan tidak terjadi kesalahan. Sebagaimana yang dikemukakan oleh Edward III dalam Agustino (2016) yang menyatakan bahwa komunikasi sangat menentukan keberhasilan dari pencapaian tujuan dari implementasi kebijakan publik. Ini menjadi penting karena semakin tinggi pengetahuan kelompok 
sasaran atas kebijakan atau program, maka akan mengurangi tingkat penolakan dan kekeliruan dalam mengaplikasikan kebijakan dalam ranah yang sesungguhnya.

Bencana alam bisa terjadi kapan saja dan dimana saja, maka kita perlu mempersiapkan dan mengantisipasi segala kemungkinan yang akan terjadi. Sehingga perlu adanya mitigasi sebagai upaya untuk mengurangi risiko bencana, baik melalui pembangunan fisik maupun penyadaran peningkatan kemampuan menghadapi ancaman. Tujuan dari Peraturan Daerah Nomor 7 Tahun 2017 ini adalah sebagai upaya yang meliputi penetapan kebijakan pembangunan yang berisiko timbulnya bencana, kegiatan pencegahan bencana, tanggap darurat dan rehabilitasi. Selain itu perda ini pun berupaya memberikan pedoman bagi pemerintah dalam penanganan bencana di Kota Sukabumi. Selain itu, perda ini terdapat sejumlah poin penting yang harus diketahui masyarakat seperti pedoman dalam upaya pencegahan dan penanganan bencana di daerah serta hak dan kewajiban masyarakat yang menjadi korban. Dan menyangkut pendanaan penanggulangan bencana yang harus memadai dalam Anggaran Pendapatan Belanja Daerah (APBD). Sebagian masyarakat belum mengetahui dan memahami dari Peraturan Daerah Nomor 7 Tahun 2017 tentang penyelenggaran penanggulangan bencana tersebut karena sosialisasi yang belum merata, sehingga perlu adanya peningkatan dalam sosialisasi kepada masyarakat.

Untuk menghadapi potensi dan kompleksitas bencana di wilayah Kota Sukabumi dimasa mendatang memerlukan suatu rencana yang lebih baik, yang sifatnya terpadu, terkoordinir dan menyeluruh. Baik dalam keadaan tidak terjadi bencana, disaat terjadinya bencana maupun setelah terjadinya bencana. Komunikasi yang baik antar pembuat kebijakan, pelaksana kebijakan dan sasaran kebijakan akan mempengaruhi keberhasilan dari implementasi kebijakan penanggulangan bencana daerah di Kota Sukabumi. Dengan memberikan sosialisasi atau simulasi yang lebih baik dan lebih digiatkan kepada masyarakat akan membantu mereka untuk mendapatkan informasi lebih dalam tentang kebencanaan serta meningkatkan kesadaran kepada masyarakat betapa pentingnya kebijakan penanggulangan bencana ini bagi kehidupan kita semua, sehingga mereka mencintai lingkungan dan alam sekitarnya.

\section{Sumber Daya}

Sumber daya merupakan suatu nilai potensi yang dimiliki oleh suatu unsur tertentu dalam kehidupan, sumber daya tidak selalu bersifat fisik, tetapi juga non-fisik. Sumber daya ada yang dapat berubah dan ada pula sumber daya yang selalu tetap. Setiap sumber daya memiliki kegunaan yang lebih spesifik dan memiliki- ciri tersendiri. Menurut Edward III dalam Agustino (2016) fasilitas fisik merupakan faktor penting dalam implementasi kebijakan. Implementator mungkin memiliki staf yang mencukupi, mengerti apa yang harus dilakukan dan memiliki wewenang untuk melaksanakan tugasnya, tetapi tanpa adanya fasilitas atau sarana dan prasarana pendukung, maka implementasi kebijakan tersebut tidak akan berhasil. Anggaran juga mempengaruhi dalam proses pelaksanaan kebijakan penanggulangan bencana, karena sumber daya finansial menjamin keberlangsungan kebijakan. Tanpa adanya dukungan finansial atau 
anggaran yang memadai, maka suatu kebijakan atau program tidak dapat berjalan efektif dan cepat dalam mencapai tujuan dan sasaran. Karena berdasarkan Peraturan Daerah Nomor 7 Tahun 2017 disebutkan bahwa ruang lingkup dari peraturan tersebut adalah kegiatan seperti prabencana, tanggap darurat, pasca bencana, hak dan kewajiban masyarakat, peran serta lembaga, organisasi kemasyarakatan, dunia usaha, pendanaan dan pengelolaan bantuan bencana serta pemantauan, evaluasi dan pengawasan. Karena kegiatan penyelenggaraan penanggulangan bencana itu merupakan hal yang kompleks, maka perlu sumber daya yang mencukupi seperti sumber daya manusianya dari segi kuantitas dan kualitas yang baik untuk penyampaian informasi, penanganan bencana dan kegiatan lain. Selain itu, dari fasilitas yang sudah memadai untuk mendukung penyelenggaraan kebijakan tersebut, maupun dari segi pendanaan atau anggaran yang sudah mencukupi pula untuk penyelenggaraan penanggulangan bencana di Kota Sukabumi.

\section{Desposisi}

Disposisi atau sikap para pelaksana merupakan variabel penting dalam implementasi kebijakan. Dimana implementasi kebijakan akan dikatakan terealisasi dengan baik, apabila dipengaruhi oleh sikap para pelaksana yang sesuai dengan kebijakan tersebut. Sikap para pelaksana sangat penting bagi pelaksana kebijakan atau organisasi, terutama organisasi yang melayani secara langsung kepada masyarakat. Komitmen, ramah tamah, tanggungjawab dan sopan santun harus dimiliki oleh pelaksana kebijakan. Dalam hal ini yang peneliti maksudkan adalah sikap para pelaksana dari pegawai Badan Penanggulangan Bencana Daerah (BPBD) Kota Sukabumi dalam melaksanakan tugas dan wewenangnya sesuai dengan Peraturan Daerah Kota Sukabumi Nomor 7 Tahun 2017 tentang penyelenggaraan penanggulangan bencana.

Menurut hasil penelitian yang dilakukan oleh Londok (2014) mengindikasikan bahwa rata-rata skor variabel disposisi atau sikap pelaksana kebijakan penanggulangan bencana di Kabupaten Minahasa Tenggara berada pada kategori rendah. Berbeda dengan penelitian ini, diposisi atau sikap pelaksana di Badan Penanggulangan Bencana Daerah (BPBD) Kota Sukabumi sudah cukup baik. Jadi disposisi ini merupakan sikap yang penting dalam pelaksanaan kebijakan penanggulangan- bencana daerah dan sebagai penentu keberhasilan dari suatu kebijakan atau program yang telah ditetapkan

\section{Struktur Birokrasi}

Berdasarkan penelitian Ristiqomah (2017) struktur organisasi pada instansi terkait- dengan penanggulangan bencana di Kecamatan Warungkiara Kabupaten Sukabumi sudah cukup baik. sama halnya yang dilakukan oleh peneliti sekarang yang memilik struktur biroraksi yang cukup pula. Ini bisa dilihat dari masing-masing pihak pelaksana dan jelasnya pembagian tugas serta pihak yang bertanggungjawab dan sudah memiliki wewenang sendiri dalam tugasnya. Hal ini bisa dilihat dari pelaksanaan penanggulangan bencana tidak ada tumpang tindih wewenang, semua melakukan 
tugasnya sesuai dengan SOP yang telah dibuat, sehingga hanya perlu adanya peningkatan dari variabel yang mempengaruhi kebijakan tersebut.

Struktur organisasi dan fragmentasi staf merupakan hal yang berpengaruh terhadap implementasi kebijakan. Apabila struktur organisasi antara pegawai terkoordinasi dengan baik, maka implementasi kebijakan tersebut akan terealisasi dengan lancar. Struktur organisasi yang ada di Badan Penanggulangan Bencana Daerah (BPBD) Kota Sukabumi terdiri dari Kepala lalu dibantu oleh Sekretaris. Dan mempunyai 4 seksi yaitu yang pertama seksi pencegahan dan kesiapsiagaan, yang kedua seksi kedaruratan dan logistik, yang ketiga seksi rehabilitasi dan rekonstruksi dan yang keempat seksi pemadam kebakaran. Hal ini sesuai dengan apa yang termuat dalam Peraturan Walikota Sukabumi Nomor 57 Tahun 2012 tentang Kedudukan, Tugas Pokok, Fungsi dan Tata Kerja Badan Penanggulangan Bencana Daerah Kota Sukabumi.

\section{SIMPULAN}

Berdasarkan hasil penelitian yang telah dideskripsikan sebelumnya oleh peneliti mengenai Implementasi Kebijakan Penanggulangan Bencana Daerah yang mengacu pada teori yang di kemukakan oleh Edward III, dapat disimpulkan bahwa dalam pelaksanaan kebijakan penanggulangan bencana daerah sebagai berikut : 1) komunikasi yang terjalin dalam hal koordinasi antara BPBD Kota Sukabumi dengan Satuan Kerja Perangkat Daerah (SKPD) lain sudah terjalin dengan cukup baik. Namun untuk komunikasi yang di lakukan BPBD Kota Sukabumi dalam melalukan kegiatan sosialisasi atau pelatihan mengenai penanggulangan bencana kepada masyarakat masih kurang dan belum merata. Serta masih kurangnya kesadaran masyarakat dalam menjaga lingkungan dengan membuang sampah di aliran sungai, 2) sumber daya yang terlibat dalam pelaksanaan kebijakan penanggulangan bencana di Badan Penanggulangan Bencana Daerah secara kuantitas dan kualitas masih kurang, selain itu sarana dan prasarananya pun masih kurang atau belum cukup memadai, serta keterbatasan anggaran mempengaruhi proses pelaksanaan kebijakan tersebut, 3) disposisi yang di nilai sudah cukup baik dilihat dari tanggungjawab dan komitmen pelaksana kebijakan terhadap tugas dalam mengimplementasikan kebijakan penanggulangan bencana daerah, sesuai dengan apa yang tercantum dalam Undang-Undang dan Peraturan mengenai penanggulangan bencana, 4) sedangkan untuk struktur birokrasi pada instansi pelaksana kebijakan penanggulangan bencana yang terkait di Kota Sukabumi sudah cukup baik. Dilihat dari masing-masing pihak pelaksana, jelasnya pembagian tugas dan pihak yang bertanggung jawab sesuai dengan SOP yang telah di tentukan serta melakukan fragmentasi pelaksana kebijakan sesuai dengan kemampuan dan kompetensi pada bidangnya, 5) faktor penghambat dari implementasi kebijakan penanggulangan bencana adalah kurangnya kesadaran masyarakat mengenai pentingnya menjaga lingkungan, kurangnya sosialisasi, fasilitas atau sarana yang ada di BPBD Kota Sukabumi belum optimal, sumber daya manusia yang kurang, faktor kelembagaan dan lingkungan yang kurang kondusif, 6) faktor pendukung dari implementasi kebijakan penanggulangan bencana adalah adanya dukungan dan bantuan dari relawan/instansi terkait yang saling 
mendukung dan memfasilitasi dalam kegiatan pasca bencana dan adanya regulasi atau peraturan tentang penyelenggaraan penanggulangan bencana.

\section{DAFTAR PUSTAKA}

Agustino, L. (2016). Dasar-dasar Kebijakan Publik. Alfabeta: Bandung. Undang-Undang Republik Indonesia Nomor 24 Tahun 2007. Tentang Penanggulangan Bencana.

Peraturan Daerah Kota Sukabumi Nomor 7 Tahun 2017. Tentang Penyelenggaraan Penanggulangan Bencana.

Ristiqomah. (2017). Implementasi Kebijakan Penanggulangan Bencana Daerah di Kabupaten Sukabumi (Studi Kasus di Kecamatan Warungkiara). Skripsi Sarjana pada Universitas Muhammadiyah Sukabumi: tidak diterbitkan.

Londok, C., I. (2014). Implementasi Kebijakan Penanggungan Bencana (Studi di Badan Penanggulangan Bencana Daerah Kabupaten Minahasa Tenggara). Skripsi pada Universitas Sam Ratulangi Manado: diterbitkan.

Setyowati, A., C, Suryaningsih \& Margaretha. (2018). Implementasi Kebijakan Penanggulangan Bencana pada Tahap Tanggap Darurat Bencana Tanah Longsor di Badan Penanggulangan Bencana Daerah Kabupaten Semarang. Skripsi pada Universitas Diponegoro: diterbitkan 